\title{
Endovascular treatment of abdominal aortic aneurysms in high-surgical-risk patients
}

\author{
Tratamento endovascular de aneurismas da aorta abdominal em \\ pacientes de alto risco cirúrgico
}

\author{
Célio Teixeira Mendonça, ${ }^{1}$ Ricardo Cesar Rocha Moreira, ${ }^{2}$ Cláudio Augusto de Carvalho, ${ }^{3}$ \\ Bárbara D'Agnoluzzo Moreira, ${ }^{4}$ Janaína Weingärtner, ${ }^{3}$ Alexandre Y. Shiomi ${ }^{5}$
}

\begin{abstract}
Background: Following the publication of a prospective randomized trial (Endovascular Aneurysm Repair Trial 2 - EVAR2) that questioned the benefits of endovascular repair of abdominal aortic aneurysms (AAA) in high-surgical-risk patients, we decided to analyze our initial and long-term results with endovascular AAA repair in this patient population.
\end{abstract}

Objective: To evaluate the operative mortality, long-term survival, frequency of secondary operations, outcome of the aneurysm sac, primary and secondary patency rates, and rupture rate after aortic stent-graft placement in high-surgical-risk patients.

Methods: From April 2002 to February 2008, 40 high-surgical and anesthetic risk patients with an AAA managed by a bifurcated aortic endograft were entered in a prospective registry. Data concerning diagnosis, operative risk, treatment and follow-up were analyzed in all patients

Results: Twenty-four Excluder ${ }^{\circledR}$ and 16 Zenith $^{\circledR}$ stent-grafts were successfully implanted. Thirty patients $(75 \%)$ were classed ASA III and $10(25 \%)$ were ASA IV. Mean aneurysm diameter was $64 \mathrm{~mm}$. Operative mortality was $2.5 \%$. Two patients required reintervention during the mean follow-up of 28.5 months. Survival rate at 3 years was $95 \%$. There were four endoleaks, one case of endotension, and one endograft limb occlusion. Primary and secondary patency rates at 3 years were 97.5 and $100 \%$, respectively. There were no ruptures.

Conclusions: Initial and long-term results with endovascular treatment of AAA in high-surgical-risk patients were satisfactory, and appear to justify such approach for this patient population.

Keywords: Abdominal aortic aneurysm, surgery, vascular prosthesis, grafts.

\section{Resumo}

Contexto: Após a publicação de um estudo prospectivo e randomizado (Endovascular Aneurysm Repair Trial 2 - EVAR2) que questionou o benefício do tratamento endovascular de aneurismas da aorta abdominal (AAA) em pacientes de alto risco cirúrgico, decidimos avaliar nossos resultados iniciais e tardios neste grupo de pacientes.

Objetivo: Avaliar a mortalidade perioperatória, a sobrevivência tardia, a freqüência das reintervenções, o comportamento dos sacos aneurismáticos, as patências primária e secundária e a incidência de rotura após o tratamento endovascular de AAA em pacientes de alto risco cirúrgico.

Métodos: Entre abril de 2002 e fevereiro de 2008, 40 pacientes de alto risco anestésico-cirúrgico portadores de AAA foram submetidos ao implante de endopróteses bifurcadas de aorta e incluídos num registro prospectivo. Os dados a respeito do diagnóstico, risco operatório, tratamento e seguimento foram analisados em todos os pacientes.

Resultados: 24 endopróteses Excluder ${ }^{\circledR}$ e 16 Zenith $^{\circledR}$ foram implantadas com sucesso. Trinta pacientes $(75 \%)$ foram classificados como ASA III e $10(25 \%)$ como ASA IV. O diâmetro médio dos AAA era de $64 \mathrm{~mm}$. A mortalidade perioperatória foi de 2,5\%. Dois pacientes necessitaram de reintervenção durante o seguimento médio de 28,5 meses. A taxa de sobrevivência aos 3 anos foi de $95 \%$. Houve quatro endoleaks, um caso de endotensão, e uma oclusão de ramo em uma endoprótese. As patências primária e secundária aos 3 anos foram de 97,5 e $100 \%$, respectivamente. Não houve nenhuma rotura.

Conclusões: Nossos resultados iniciais e tardios do tratamento endovascular de AAA em pacientes de alto risco são satisfatórios e parecem justificar a indicação deste tratamento neste grupo de pacientes.

Palavras-chave: Aneurisma da aorta abdominal, cirurgia, prótese vascular, enxertos.

1. Professor and Chief of Vascular and Endovascular Surgery, Universidade Positivo, Curitiba, PR, Brazil. MSc and PhD in Surgery, Universidade Federal do Paraná (UFPR), Curitiba, PR, Brazil. Post-doctoral fellowship in Vascular and Interventional Radiology, Medical University of South Carolina, USA. Member, SBACV.

2. Head, Vascular Surgery Service, Hospital Nossa Senhora das Graças (HNSG) and Hospital Universitário Cajuru - Pontifícia Universidade Católica do Paraná (HUC-PUCPR), Curitiba, PR, Brazil. MSc. and PhD in Surgery, UFPR, Curitiba, PR, Brazil. Member, SBACV.

3. Vascular Surgeon, Hospital Universitário da Cruz Vermelha do Paraná, Universidade Positivo, Curitiba, PR, Brazil.

4. Former resident, Vascular Surgery Service, HUC-PUCPR, Curitiba, PR, Brazil. Clinical Fellow, Wayne State University, USA.

5. Resident, Vascular Surgery Service, HNSG, Curitiba, PR, Brazil.

No conflicts of interest declared concerning the publication of this article.

Manuscript received August 17, 2008. Accepted December 11, 2008.

J Vasc Bras 2009;8(1):56-64.

Copyright $\odot 2009$ by Sociedade Brasileira de Angiologia e de Cirurgia Vascular 
Table 1 - Anatomic inclusion criteria for $\operatorname{EVAR}^{3,9}$

\author{
AAA diameter $\geq 5.5 \mathrm{~cm}$ \\ Proximal neck length $\geq 15 \mathrm{~mm}$ \\ Proximal neck angle $<60^{\circ}$ \\ External iliac artery diameter $\geq 7 \mathrm{~mm}$
}

Absence of thrombi of extensive calcification in the proximal neck ( $>50 \%$ of the circumference)

AAA = abdominal aortic aneurysm; EVAR = endovascular abdominal aortic aneurysm repair.

\section{Introduction}

Two prospective and randomized studies ${ }^{1,2}$ that analyzed low-surgical-risk patients reported a significant reduction in immediate morbidity and mortality rates following endovascular abdominal aortic aneurysm repair (EVAR), when compared to conventional open repair. Nevertheless, the uncertainties concerning the long-term outcome of aortic endografts have prompted many scientific societies, among them the American Association for Vascular Surgery and the Society for Vascular Surgery, ${ }^{3}$ to recommend that EVAR should be reserved for the elderly and the so-called high-surgicalrisk patients, as long as their anatomy is favorable.

However, recent studies on endovascular AAA repair have reported both a high frequency of reinterventions ${ }^{4-6}$ and elevated rates of immediate and late morbidity and mortality in high-surgical-risk patients, ${ }^{6}$ which has raised the question of whether EVAR is the best treatment option for such patients.

This study describes our initial and long-term results with endovascular repair of AAA in 40 high-surgicalrisk patients consecutively treated by the same group of surgeons, using bifurcated endografts, with a mean follow-up of 28.5 months. As additional information, the aneurysm-related mortality in these patients will be compared with case series published in the literature that evaluated the natural history of AAA in high-surgicalrisk patients left untreated.

\section{Patients and methods}

From April 2002 to February 2008, 45 patients with infrarenal AAA managed by a bifurcated aortic endograft were entered in a prospective registry. This study was approved by the Research Ethics Committee of Hospital Universitário da Cruz Vermelha do Paraná (Universidade Positivo). All patients in the preoperative period were submitted to contrast-enhanced computed tomography with three-dimensional reconstruction (angioCT-3D). Data concerning diagnosis, operative risk, treatment and follow-up were prospectively collected in our protocol. Forty patients were classified as high-surgical-risk and with anatomic characteristics favorable to EVAR (Table 1), and are the focus of this study. Exclusion criteria were low-surgical-risk patients $(\mathrm{n}=3)$ and patients with ruptured AAA $(\mathrm{n}=2)$.

Patients who had one or more of the criteria $^{7-9}$ listed in Table 2 were classified as high-risk.

\section{Technique of endovascular repair of abdominal aortic aneurysms}

Informed consent was obtained from all patients after the technique, risks and possible complications were discussed in details. Twenty-four Excluder ${ }^{\circledR}$ (W. L. Gore \& Assoc., Flagstaff, Arizona) (Figure 1), and 16 Zenith $^{\circledR}$ (Cook Inc., Bloomington, Indiana) stent-grafts were used (Figure 2). All procedures were performed in the surgical suites of Hospital Universitário da Cruz Vermelha do Paraná and Hospital Nossa Senhora das Graças. Patients were prepared as if they were going to be submitted to an open surgery, in case a conversion to open treatment was required due to failures in the endovascular technique or due to occurrence of serious complications. All patients were operated under epidural anesthesia. At the beginning of the procedure, $1 \mathrm{~g}$ of intravenous cefazolin $\left(\mathrm{Kefazol}^{\circledR}\right)$ was administered for 
Table 2 - Criteria to be considered high-surgical or anesthetic risk patient ${ }^{7-9}$
A) Age $\geq 80$ years
B) Serum creatinine level $\geq 3 \mathrm{mg} / \mathrm{dL}$
C) Severe pulmonary dysfunction (defined as forced expiratory volume in first second $<1 \mathrm{~L}, \mathrm{PaO}_{2}<60 \mathrm{mmHg}, \mathrm{PaCO}_{2}>45$ $\mathrm{mmHg}$ or small effort dyspnea)
D) Severe cardiac dysfunction [defined as recent acute myocardial infarction (less than 3 months), ejection fraction of the left ventricle $\leq 25 \%$, recent or recurrent symptomatic congestive heart failure (less than 3 months), severe and diffuse coronary artery disease (no anatomic conditions for revascularization) with or without unstable angina, symptomatic aortic stenosis and unstable angina at rest]

$\mathrm{L}=$ liter $; \mathrm{PaO}_{2}=$ partial pressure of oxygen $\mathrm{PaCO}_{2}=$ partial pressure of carbon dioxide.

infection prophylaxis. After dissection of common femoral arteries, which was the access used in all patients, endovenous heparin was administered (5,000 U). All stent-grafts were implanted under fluoroscopy using a Philips ${ }^{\circledR}$ BV300 device. Digital subtraction angiography was performed at the end of the procedure in all cases.

\section{Postoperative follow-up}

Postoperative follow-up consisted of clinical examination and angioCT-3D or Doppler ultrasonography in the first, sixth and 12th month after EVAR, and at every 12 months thereafter.

The main objective of this study was to evaluate patients' operative mortality and late survival rate. Secondary objectives were to determine primary and secondary patency rates, frequency of reinterventions and outcome of the aneurysm sacs after stent-graft implantation. Operative mortality was defined as death during initial hospital stay or death due to any cause up to 30 days after stent-graft implantation. Reintervention was defined as any surgical or endovascular procedure performed immediately or some time after stent-graft implantation, in order to maintain a satisfactory clinical outcome or to treat a specific complication related to the stent-graft or the aneurysm. The outcome of the aneurysm sac was evaluated by postoperative measurement of aneurysm cross-sectional diameter in tomographies performed during follow-up.

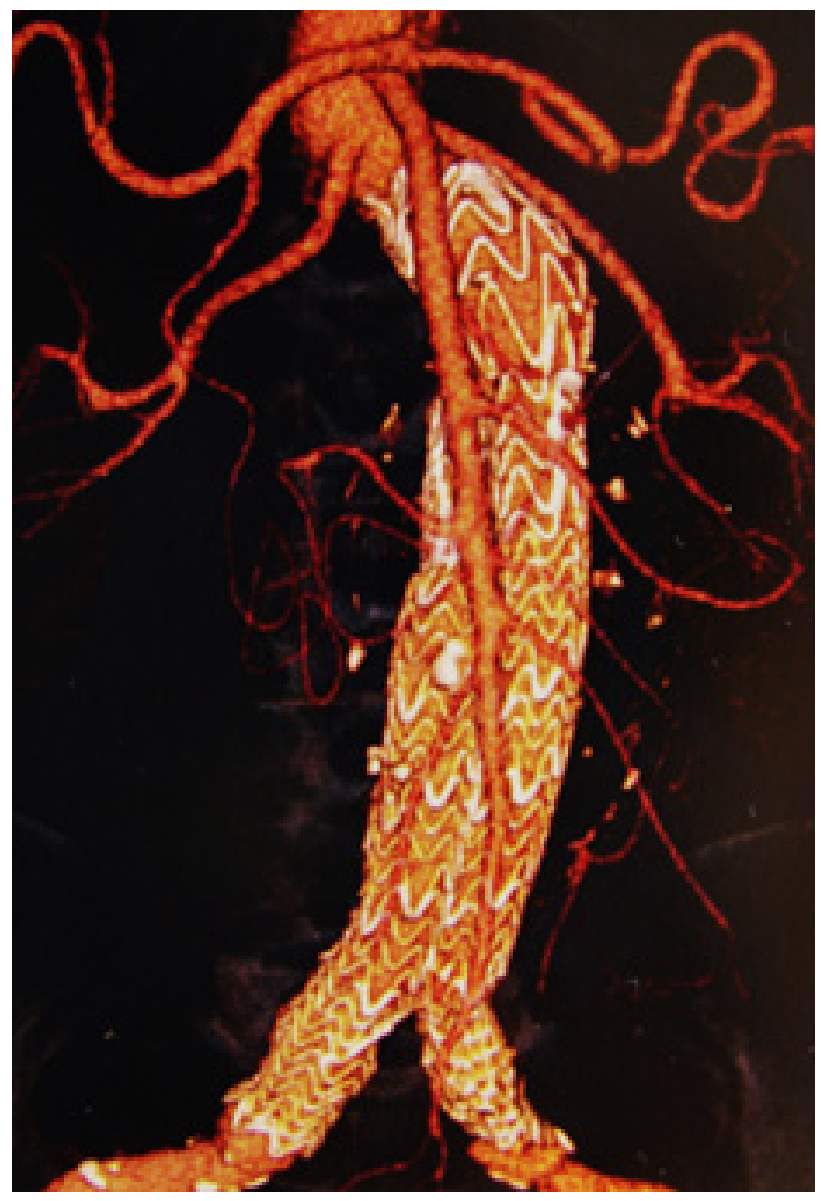

Figure 1 - AngioCT-3D of patient with abdominal aortic aneurysm $(7.2 \mathrm{~cm}$ in diameter) treated with an Excluder ${ }^{\circledR}$ bifurcated stent-graft

In addition to the data provided above, duration of procedures, blood loss, hospital stay and intensive care unit (ICU) stay times were also analyzed. 


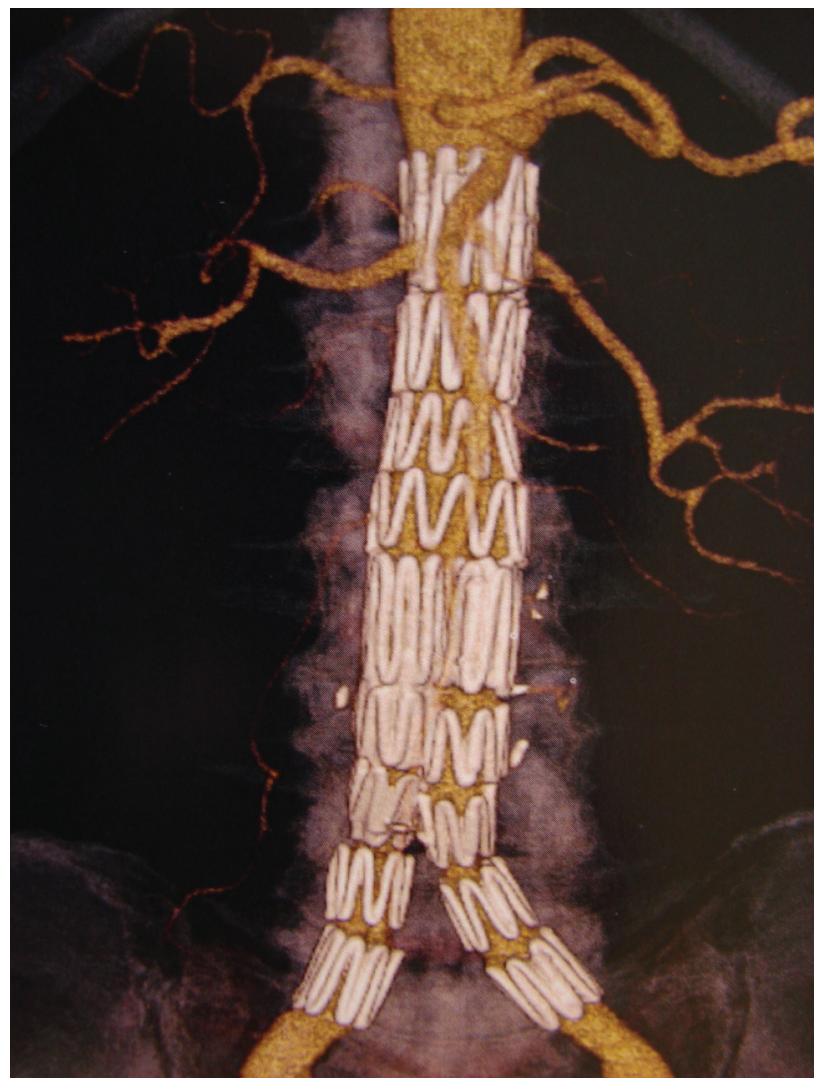

Figure 2 - AngioCT-3D of patient with abdominal aortic aneurysm $(6.3 \mathrm{~cm}$ in diameter) treated with a Zenith $^{\circledR}$ bifurcated stent-graft

\section{Statistical analysis}

Statistical analysis was performed using STATGRAPHICS (version 5.1). Variables were described as mean \pm standard deviation, or percentage. The KaplanMeier method was used to calculate the estimate for survival probability.

\section{Results}

A total of 40 high-surgical-risk patients ( 33 male and seven female) were included in the study. Mean age was 72.7 years (range: 54-91). Risk factors and associated diseases are shown in Table 3. Of the 26 patients with severe cardiac dysfunction, nine had severe and diffuse coronary artery disease without anatomic conditions for revascularization (six with and three without unstable angina), nine had ejection fraction of the left ventricle $\leq$ $25 \%$, and eight had multiple associated heart problems (recent or recurrent symptomatic congestive heart failure, arrhythmias and coronary artery disease). Of the 13 patients with severe pulmonary dysfunction, four had small effort dyspnea, four had forced expiratory volume in first second $<1 \mathrm{~L}$, three had $\mathrm{PaO}_{2}<60 \mathrm{mmHg}$, and two had concomitant pulmonary problems (small effort dyspnea and pulmonary emphysema requiring home oxygen).

According to the classification of the American Society of Anesthesiologists Physical Class, ${ }^{10} 30$ patients were classified as ASA III (75\%), and 10 as ASA IV (25\%). All ASA IV patients had at least two criteria for high risk (age $\geq 80$ years, renal failure, severe pulmonary dysfunction or severe cardiac dysfunction), associated with multiple severe comorbidities. Patients classified as ASA III had at least one of the high risk criteria associated with other minor problems such as hypertension, tobacco abuse, or diabetes. No patient had more than two criteria for high risk.

EVAR was technically feasible in 40 patients $(100 \%)$. Mean aneurysm diameter was $64.2 \pm 7.7 \mathrm{~mm}$. Mean proximal neck length was $22.5 \mathrm{~mm}$ (range: $15-32 \mathrm{~mm}$ ), and mean proximal neck diameter was $22.8 \pm 3.3 \mathrm{~mm}$.

Four patients required balloon angioplasty of the common iliac arteries to facilitate stent-graft implantation. Seven patients were submitted to embolization of one of the internal iliac arteries due to presence of ipsilateral common iliac artery aneurysm, and the stentgraft landing zone was in the external iliac artery.

Mean duration of procedures was 181.6 minutes. Mean hospital stay was 3.1 days (minimum $=1$ day; maximum $=5$ days). Mean hospital stay at ICU was 25.9 hours (minimum $=0$ hour; maximum $=72$ hours). Mean operative blood loss was $180.3 \mathrm{~mL}$ (minimum = $100 \mathrm{~mL}$; maximum $=500 \mathrm{~mL}$ ).

Operative mortality was $2.5 \%(1 / 40)$ due to an acute myocardial infarction on the seventh postoperative day. This was an 85-year-old male patient with history of many myocardial infarctions (ejection fraction of the left ventricle $=20 \%$ ).

Mean follow-up time was 28.5 months. Late mortality was $2.56 \%(1 / 39)$. This death occurred on the 14 th 
Table 3 - Characteristics of patients submitted to EVAR $(n=40)$

\begin{tabular}{|c|c|}
\hline Variables & Data \\
\hline \multicolumn{2}{|l|}{ Age (years) } \\
\hline Mean \pm SD & $72.7 \pm 8.6$ \\
\hline Variation & $54-91$ \\
\hline Age $\geq 80$ years & $11(27.5 \%)$ \\
\hline \multicolumn{2}{|l|}{ Gender } \\
\hline Male & $33(82.5 \%)$ \\
\hline Female & $7(17.5 \%)$ \\
\hline \multicolumn{2}{|l|}{ Follow-up (days) } \\
\hline Mean \pm SD & $853.95 \pm 88.41$ \\
\hline Variation & $7-2,179$ \\
\hline Median & 793.5 \\
\hline \multicolumn{2}{|l|}{ AAA diameter (mm) } \\
\hline Mean $\pm \mathrm{SD}$ & $64.25 \pm 7.7$ \\
\hline Variation & $55-96$ \\
\hline \multicolumn{2}{|l|}{ Associated diseases } \\
\hline Severe cardiac dysfunction & $26(65 \%)$ \\
\hline Severe pulmonary dysfunction & $13(32.5 \%)$ \\
\hline Renal failure (creatinine $>3 \mathrm{mg} / \mathrm{dL}$ ) & $0(0 \%)$ \\
\hline Diabetes & $5(12.5 \%)$ \\
\hline Hypertension & $22(55 \%)$ \\
\hline Smoking & $21(52.5 \%)$ \\
\hline Peripheral vascular disease & $8(20 \%)$ \\
\hline Previous brain stroke & $1(2.5 \%)$ \\
\hline
\end{tabular}

AAA = abdominal aortic aneurysm; EVAR = endovascular abdominal aortic aneurysm repair; SD = standard deviation.

postoperative month, and was caused by an acute myocardial infarction in a patient with severe coronary artery disease (severe and diffuse coronary artery disease without anatomic conditions for revascularization). Estimate of survival probability at 3 years was 95\% (Figure 3). Primary and secondary patency rates at 3 years were 97.5 and $100 \%$, respectively. Three patients had buttock claudication after internal iliac artery embolization, with complete resolution of symptoms between 3 and 12 months.

There were three type II endoleaks (two early and one late), one type Ib endoleak, and one case of endotension. The two early type II endoleaks resolved spontaneously 3 and 6 months after the procedure. Two patients $(5 \%)$ required reintervention during the follow-up. The first patient was submitted to implantation of an Excluder ${ }^{\circledR}$ bifurcated endograft; its main body was made of low-permeability polytetrafluoroethylene (PTFE) and the contralateral leg of high-permeability PFTE. This patient had an immediate type Ib endoleak that sealed after balloon angioplasty. Doppler ultrasonography and angioCT-3D 2 years after the initial procedure showed that his aneurysm diameter had increased (this was the only patient in this series to show an increase in AAA diameter after EVAR). Digital 


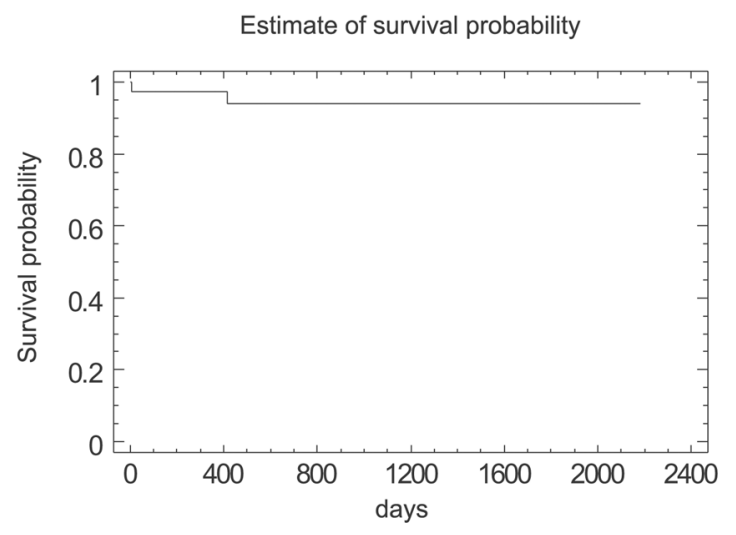

Figure 3 - Estimate of survival probability using the KaplanMeier method for 40 high-surgical-risk patients submitted to endovascular treatment of abdominal aortic aneurysms

angiography showed a late type II endoleak, maintained by the inferior mesenteric artery (IMA), which was treated by laparoscopic ligation of this artery. As his AAA was still growing after IMA ligation, we then thought that the patient could have endotension, caused by material extravasation through the contralateral leg of the Excluder ${ }^{\circledR}$ stent-graft. ${ }^{11,12}$ The patient was then submitted to implantation of a second contralateral leg (made of low-permeability PTFE), and results of control tomography were not ready until the moment this report was written. The second patient that required reintervention had occlusion of the right limb of a Zenith ${ }^{\circledR}$ stent-graft with lower limb ischemia; treatment consisted of implantation of a balloon-expandable stent and the patient had good clinical course. The aneurysm sac decreased in size by 2 to $21 \mathrm{~mm}$ in 22 patients in this series $(55 \%)$. In the 17 remaining patients, the aneurysm sac remained stable during the entire follow-up period. Acute renal failure that occurred in one patient was precipitated by use of iodinated contrast and responded well to clinical treatment (hydration and diuretics). There was no case of AAA rupture after EVAR.

\section{Discussion}

Operative mortality in this series of 40 high-surgicalrisk patients submitted to endovascular AAA repair was $2.5 \%$. Frequency of reinterventions during the 28.5-month follow-up was 5\% (two cases). Survival rate at 3 years was $95 \%$, and aneurysm sac diameters were reduced in more than half of cases. None of the deaths observed during follow-up were due to AAA rupture or stent-graft complications. The main complications were caused by occurrence of endoleaks and endotension in three patients ( $7.5 \%$ of cases) and by occlusion of the right limb of a stent-graft ( $2.5 \%$ of cases).

This study has some limitations: although patients' data were collected in a prospective register, analysis was retrospective and there was no control group. The sample is relatively small, but no patient in this series was lost during follow-up.

Previous studies have suggested that endovascular AAA repair may be a good alternative to open repair for patients with severe comorbidities. ${ }^{13-19}$ Operative mortality rates in the literature range from 0 to $5.3 \%$ for this population of high-risk patients. The EVAR $2,{ }^{6} \mathrm{a}$ prospective and randomized study recently performed in the United Kingdom comparing surveillance and endovascular repair of AAA in patients for whom open treatment was contraindicated reported a mortality rate on day 30 of $9 \%$, and a survival rate of only $34 \%$ (after a 4-year follow-up) in the endovascular group. This raises the concern that EVAR might not provide any advantage when compared with non-intervention in high-risk patients.

It might be considered that the results of this study were better than those of EVAR2 because our inclusion criteria for high risk were more lenient. However, the criteria used in this study (cardiac, pulmonary and renal) were very similar to those of EVAR $2,{ }^{8}$ so that $92.5 \%$ (37/40) of our patients would have probably qualified as EVAR2 patients. Thirty patients $(75 \%)$ in this series were ASA class III, and 10 (25\%) were ASA class IV. Such patients are classically considered as high risk for open treatment of AAA. ${ }^{13}$ The only difference between both studies is that age greater than 80 years was considered as an independent criterion for high risk only in this study. Anyhow, of the 11 patients older than 80 years, five had severe cardiac dysfunction, three had severe pulmonary dysfunction and only three (7.5\%) had age as an isolated high risk factor (and probably would not have been included in the EVAR2). 
Table 4 - Literature review on endovascular AAA repair in high-risk patients

\begin{tabular}{|c|c|c|c|c|c|}
\hline Study & $\mathbf{n}$ & $\begin{array}{c}\text { Mean age } \\
\text { (years) }\end{array}$ & $\begin{array}{c}\text { Mean AAA } \\
\text { diameter } \\
(\mathbf{m m})\end{array}$ & $\begin{array}{c}\text { Operative } \\
\text { mortality } \\
(\%)\end{array}$ & $\begin{array}{c}\text { Survival } \\
(\%)\end{array}$ \\
\hline EUROSTAR $^{18}$ & 550 & 72.6 & 58.3 & $4.8-5.3$ & 68 (3 years) \\
\hline Sicard et al. ${ }^{15}$ & 565 & 76.6 & 64 & 2.9 & 56 (4 years) \\
\hline Bush et al. ${ }^{13}$ & 788 & 72.9 & Not available & 3.4 & 85 ( 2 years) \\
\hline Chuter et al. ${ }^{20}$ & 116 & 75 & 63 & 3.4 & 76 (3 years) \\
\hline $\begin{array}{l}\text { Jean-Baptiste et } \\
\text { al. }^{21}\end{array}$ & 92 & 77 & 58 & 4.3 & 85 (3 years) \\
\hline EVAR $^{6}$ & 166 & 76.8 & 64 & 9 & 34 (4 years) \\
\hline This study & 40 & 72.7 & 64.2 & 2.5 & 95 (3 years) \\
\hline
\end{tabular}

AAA $=$ abdominal aortic aneurysm.

In addition, other studies ${ }^{13,15,18,20,21}$ including large numbers of patients (Table 4) corroborate our favorable results obtained with EVAR in patients considered at high-risk for conventional open repair.

There are at least two possible explanations for the differences in results found between this study and the EVAR2. First, 14 patients in the EVAR2 died preoperatively during the 57 -day mean interval between randomization and repair. Therefore, $52 \%$ of the perioperative deaths (14/27) and $19 \%$ of total deaths in the EVAR arm occurred preoperatively. In addition, nine patients died from AAA rupture before their elective EVAR date, accounting for $45 \%$ of the 20 aneurysm-related deaths in the EVAR arm of the EVAR2. Many of these deaths could have been avoided if the interval between randomization and repair had been shorter. An interesting fact was that 47 patients in the surveillance group of the EVAR2 (28\%) were operated on in violation of the study protocol. Curiously, operative mortality rate was only $2.1 \%$ (similar to ours). Second, the medical treatment administered to all of our patients (statins and betablockers) was not optimal in nearly half of the patients in the EVAR2 study; ${ }^{6}$ it is known that medical treatment has confirmed influence on patient survival. ${ }^{22,23}$

Various studies that analyzed the natural history outcomes of patients who did not undergo surgery because they were considered unfit for traditional open repair because of comorbid factors have shown a high incidence of death due to AAA rupture. ${ }^{24-26}$ In a prospective, multicenter observational study, Lederle et al. ${ }^{24}$ reported 1-year rupture rate of $9.4 \%$ in patients with AAAs from 5.5 to $5.9 \mathrm{~cm}$ in diameter; $19.1 \%$ in patients with AAAs from 6.5 to $6.9 \mathrm{~cm}$ in diameter, and $32.5 \%$ for AAAs $\geq 7 \mathrm{~cm}$. These high rates of death due to AAA rupture were based on an autopsy rate of $46 \%$; therefore, the true death rate caused by AAA rupture is almost certainly higher. Conway et al. ${ }^{25}$ reported that mortality caused by AAA rupture after a 3-year follow-up in 106 patients considered as high-risk for open treatment was $36 \%$ in patients with aneurysms between 5.5 and $5.9 \mathrm{~cm}$ in diameter, $50 \%$ for aneurysms between 6.0 and $7.0 \mathrm{~cm}$, and $55 \%$ for aneurysms greater than $7 \mathrm{~cm}$ in diameter. Jones et al. ${ }^{26}$ observed that mortality caused by AAA rupture after a 3-year follow-up in 50 high-risk patients was $28 \%$ for aneurysms between 5.0 and $5.9 \mathrm{~cm}$ in diameter and $41 \%$ for aneurysms greater than $6 \mathrm{~cm}$ in diameter. With a mean diameter of $6.4 \mathrm{~cm}$, the mortality rate associated with AAA rupture in this study was $0 \%$ in 28.5 months, dramatically less than the mortality rates reported in the three natural history studies above.

Our initial and long-term results with endografts for treatment of AAA in high-surgical-risk patients were satisfactory, with operative mortality rate of $2.5 \%, 3$-year survival rate of $95 \%$ and incidence of reintervention of 
only $5 \%$. In our opinion, these results justify endovascular repair for this group of patients, as long as the aortic anatomy is favorable.

Non-intervention in patients with AAA and highsurgical-risk is only justified in those with an extremely short life expectancy, in whom the risk of death associated with the surgical procedure is higher than the risk of death caused by aneurysm rupture.

\section{References}

1. EVAR Trial Participants. Endovascular aneurysm repair versus open repair in patients with abdominal aortic aneurysm (EVAR trial 1): randomised controlled trial. Lancet. 2005;365:2179-86.

2. Prinssen M, Verhoeven EL, Buth J, et al. A randomized trial comparing conventional and endovascular repair of abdominal aortic aneurysms. N Engl J Med. 2004;351:1607-18.

3. Brewster DC, Cronenwett JL, Hallett JW Jr, et al. Guidelines for the treatment of abdominal aortic aneurysms: report of a subcommittee of the Joint Council of the American Association for Vascular Surgery and Society for Vascular Surgery. J Vasc Surg. 2003;37:1106-17.

4. Blankensteijn JD, de Jong SE, Prinssen M, et al. Two-year outcomes after conventional or endovascular repair of abdominal aortic aneurysms. N Engl J Med. 2005;352:2398-405.

5. Becquemin JP, Kelley L, Zubilewicz T, Desgranges P, Lapeyre M, Kobeiter H. Outcomes of secondary interventions after abdominal aortic aneurysm endovascular repair. J Vasc Surg. 2004;39:298-305.

6. EVAR trial participants. Endovascular aneurysm repair and outcome in patients unfit for open repair of abdominal aortic aneurysm (EVAR trial 2): randomised controlled trial. Lancet. 2005;365:2187-92.

7. Menard MT, Chew DK, Chan RK, et al. Outcome in patients at high risk after open surgical repair of abdominal aortic aneurysm. J Vasc Surg. 2003;37:285-92.

8. Brown LC, Epstein D, Manca A, Beard JD, Powell JT, Greenhalgh RM. The UK Endovascular Aneurysm Repair (EVAR) Trials: Design, Methodology and Progress. Eur J Vasc Endovasc Surg. 2004;27:372-81.

9. Mendonça CT, Moreira RC, Timi JR, et al. Comparação entre os tratamentos aberto e endovascular dos aneurismas da aorta abdominal em pacientes de alto risco cirúrgico. J Vasc Bras. 2005;4:232-42.

10. Wolters U, Wolf T, Stützer H and Schröder T. ASA classification and perioperative variables as predictors of postoperative outcome. Br J Anaesth. 1996;77:217-22.
11. Tanski W 3rd, Fillinger M. Outcomes of original and lowpermeability Gore Excluder ${ }^{\circledR}$ endoprosthesis for endovascular abdominal aortic aneurysm repair. J Vasc Surg. 2007;45:243-9.

12. Kougias P, Lin PH, Dardik A, Lee WA, El Sayed HF, Zhou W. Successful treatment of endotension and aneurysm sac enlargement with endovascular stent graft reinforcement. J Vasc Surg. 2007;46:124-7.

13. Bush RL, Johnson ML, Hedayati N, Henderson WG, Lin PH, Lumsden AB. Performance of endovascular aortic aneurysm repair in high-risk patients: results from the Veterans Affairs National Surgical Quality Improvement Program. J Vasc Surg. 2007;45:227-33.

14. Iannelli G, Monaco M, Di Tomasso L, et al. Endovascular vs. open surgery of abdominal aortic aneurysm in high risk patients: a single center experience. Thorac Cardiovasc Surg. 2005;53:291-4.

15. Sicard GA, Zwolak RM, Sidawy AN, White RA, Siami FS, Society for Vascular Surgery Outcomes Committee. Endovascular abdominal aortic aneurysm repair: long-term outcome measures in patients at high-risk for open surgery. J Vasc Surg. 2006;44:229-36.

16. Sukhija R, Aronow WS, Mathew J, et al. Treatment of abdominal aortic aneurysms with an endovascular stentgraft prosthesis in 96 high-risk patients. Cardiol Rev. 2005;13:165-6.

17. Allaqaband S, Mortada ME, Tumuluri R, Kumar A, Bajwa TK. Endovascular stent-graft repair of abdominal aortic aneurysms in high-risk patients; a single center experience. $\mathrm{J}$ Interv Cardiol. 2004;17:71-9.

18. Buth J, van Marrewijk CJ, Harris PL, et al. Outcome of endovascular abdominal aortic aneurysm repair in patients with conditions considered unfit for an open procedure: a report on the EUROSTAR experience. J Vasc Surg. 2002;35:211-21.

19. Sbarigia E, Speziale F, Ducasse E, et al. What is the best management for abdominal aortic aneurysm in patients at high surgical risk? A single-center review. Int Angiol. 2005;24:70-4.

20. Chuter TA, Reilly LM, Faruqi RM, et al. Endovascular aneurysm repair in high-risk patients. J Vasc Surg. 2000;31:122-33.

21. Jean-Baptiste E, Hassen-Khodja R, Bouillanne PJ, Haudebourg P, Declemy S, Batt M. Endovascular repair of infrarenal abdominal aortic aneurysms in high-risk-surgical patients. Eur J Vasc Endovasc Surg. 2007;34:145-51.

22. Kertai MD, Boersma E, Westerhout CM, et al. A combination of statins and beta-blockers is independently associated with reduction in the incidence of perioperative mortality and non-fatal myocardial infarction in patients undergoing abdominal aortic aneurysm surgery. Eur J Vasc Endovasc Surg. 2004;28:343-52.

23. Kertai MD, Boersma E, Westerhout CM, et al. Association between long-term statin use and mortality after successful abdominal aortic aneurysm surgery. Am J Med. 2004;116:96-103.

24. Lederle FA, Johnson GR, Wilson SE, et al. Rupture rate of large abdominal aortic aneurysms in patients refusing or unfit for elective repair. JAMA. 2002;287:2968-72. 
25. Conway KP, Byrne J, Townsend M, Lane IF. Prognosis of patients turned down for conventional abdominal aortic aneurysm repair in the endovascular and sonographic era: Szilagyi revisited? J Vasc Surg. 2001;33:752-7.

26. Jones A, Cahill D, Gardham R. Outcome in patients with a large abdominal aortic aneurysm considered unfit for surgery. Br J Surg. 1998;85:1382-4.
Correspondence:

Dr. Célio Teixeira Mendonça

Rua Visconde do Rio Branco, 1717, $3^{\circ}$ andar

CEP 80420-210 - Curitiba, PR, Brazil

Tel.: +55 (41) 3322-5422, +55 (41) 8412-2969

E-mail: celiotm@brturbo.com.br

\section{O conteúdo do J Vasc Bras está disponivel em português e em inglês}

no site do Jornal Vascular Brasileiro em

\section{www.jvascbr.com.br}

